\title{
Benefits and Limitations of Non-Transgenic Micronutrient Biofortification Approaches
}

\author{
Edward Marques $^{1}\left(\mathbb{D}\right.$, Heather M. Darby ${ }^{2}$ and Jana Kraft ${ }^{1,3, * \mathbb{D}}$ \\ 1 Department of Animal and Veterinary Sciences, University of Vermont, Burlington, VT 05405, USA; \\ Edward.Marques@uvm.edu \\ 2 The Department of Plant and Soil Sciences, University of Vermont, Burlington, VT 05405, USA; \\ Heather.Darby@uvm.edu \\ 3 Department of Medicine, Division of Endocrinology, Metabolism and Diabetes, University of Vermont, \\ Colchester, VT 05446, USA \\ * Correspondence: Jana.Kraft@uvm.edu; Tel.: +1-802-656-5489
}

check for updates

Citation: Marques, E.; Darby, H.M.; Kraft, J. Benefits and Limitations of

Non-Transgenic Micronutrient Biofortification Approaches. Agronomy 2021, 11, 464. https://doi.org/ 10.3390 /agronomy11030464

Academic Editors:

Massimiliano D'Imperio,

Francesco Serio, Francesco Di Gioia,

Agnieszka Sękara and Carla

Sancho dos Santos

Received: 11 February 2021

Accepted: 26 February 2021

Published: 3 March 2021

Publisher's Note: MDPI stays neutral with regard to jurisdictional claims in published maps and institutional affiliations.

Copyright: (c) 2021 by the authors. Licensee MDPI, Basel, Switzerland This article is an open access article distributed under the terms and conditions of the Creative Commons Attribution (CC BY) license (https:// creativecommons.org/licenses/by/ $4.0 /)$

\begin{abstract}
Increasing the amount of micronutrients in diets across the world is crucial to improving world health. Numerous methods can accomplish this such as the biofortification of food through biotechnology, conventional breeding, and agronomic approaches. Of these, biofortification methods, conventional breeding, and agronomic approaches are currently globally accepted and, therefore, should be the primary focus of research efforts. This review synthesizes the current literature regarding the state of biofortified foods through conventional breeding and agronomic approaches for crops. Additionally, the benefits and limitations for all described approaches are discussed, allowing us to identify key areas of research that are still required to increase the efficacy of these methods. The information provided here should provide a basal knowledge for global efforts that are combating micronutrient deficiencies.
\end{abstract}

Keywords: conventional breeding; agronomic; fertilizers; biofertilizers; hydroponic; microorganisms; nutri-priming

\section{Introduction}

Micronutrient deficiencies, also known as hidden hunger, are a global health issue that affects approximately two billion people, with the majority of cases found in Asia, Africa, and Latin America [1-3]. The most common micronutrient deficiencies concern iron, iodine, zinc, and vitamin A [4]. In general, micronutrient deficiencies can have severe health ramifications such as impaired cognitive development, stunted growth, perinatal complications, and even premature death [5]. For instance, vitamin A deficiency is the leading cause of childhood blindness (i.e., xerophthalmia), and it has been estimated that over 190 million children are affected by this deficiency worldwide [4].

Numerous strategies and methods have been recommended to combat micronutrient deficiencies, one of which is biofortification, or the process of increasing essential nutrients in food through biotechnology, conventional breeding, and agronomic practices [2,6] (Figure 1). Importantly, biofortification is generally considered a sustainable, cost-effective, and efficient method to increase micronutrients in the diets of underserved populations [6-8]. Additionally, biofortified food has become a niche commodity in developed countries in the form of functional foods, which are foods with a potentially positive effect on human health in addition to basic nutrition [9]. As some consumers have become more aware of particular nutrients' positive health effects, their food preference has shifted to foods enriched with those nutrients [10-13]. For example, NuLin ${ }^{\circledR}$ is a flax (Linum usitatissimum L.) variety developed to have a high alpha-linolenic acid content $[14,15]$. As a result, it is utilized to increase omega- 3 concentrations in food and animal feed. As of 2019, the global functional food market size was estimated to be $\$ 173.26$ billion and is projected to reach $\$ 309$ billion by 2027 [16]. 


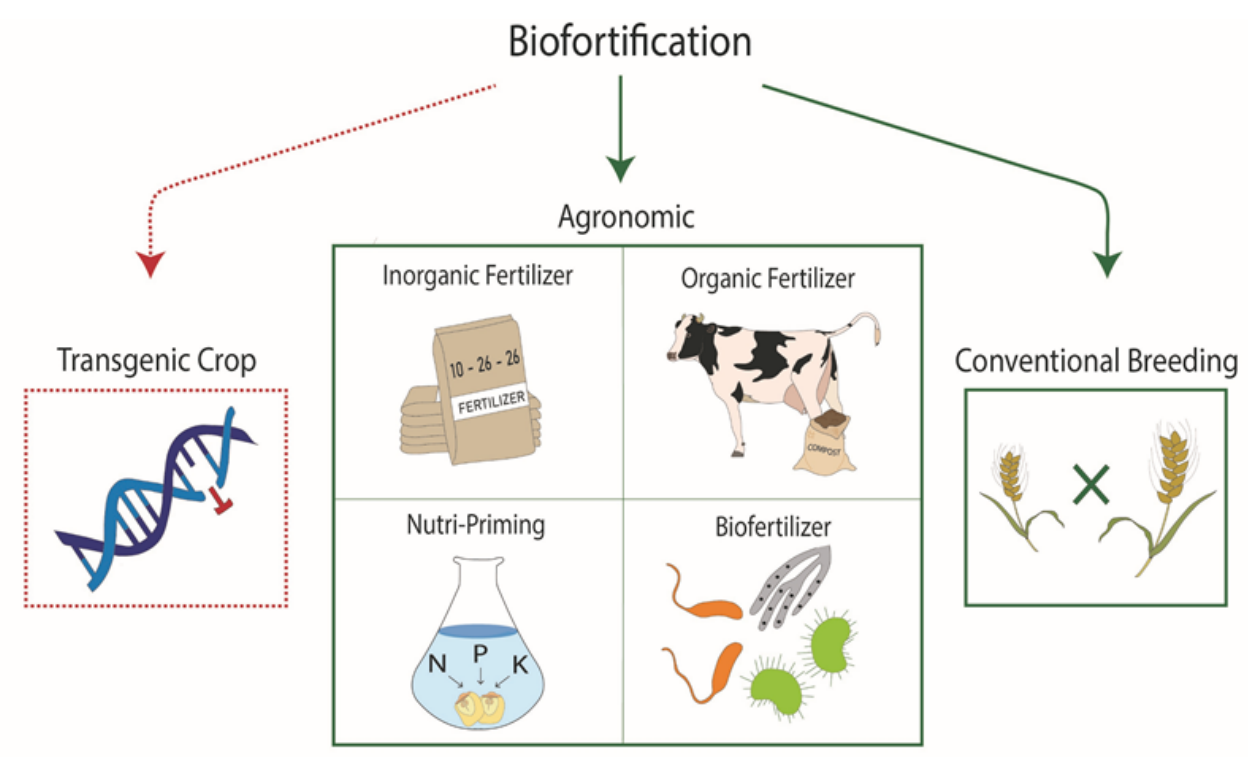

Figure 1. The three primary biofortification approaches for crops are transgenic, agronomic, and conventional breeding. Green solid arrows signify globally accepted approaches, while the red dashed arrows signify non-globally accepted approaches. Illustrated by Jorge Ruiz-Arocho.

Despite the benefits of biofortification to combat nutrient deficiencies, some biofortification methods have drawn major criticism from the public, primarily biofortification of food through transgenic biotechnological processes, or the process of introducing a gene from one organism into the genome of another organism [17-20]. Even though limited scientific evidence suggests foods developed by transgenic biotechnology have detrimental effects on human health, the majority of criticism focuses on its safety and ethical concerns [17-20]. In a recent survey conducted by the Pew Research Center with 1480 correspondents, $39 \%$ of Americans considered genetically modified foods harmful to human health, while only $10 \%$ believed they were beneficial [21]. The negative perception of transgenic crops is even higher in Europe and also occurs in regions where malnutrition is prevalent such as Africa and Asia [18,22]. Due to the strong negative public perception of these foods, many consumers refuse to purchase or consume transgenic foods. Therefore, for biofortification to have an actual impact on health around the globe, for now, biofortification research may need to shift to other non-transgenic processes that have greater public acceptance. This review will identify and describe non-transgenic biofortification processes for plant-derived products and discuss the benefits and limitations of each (Table 1). The overarching goal of this review is to explore various strategies to biofortify foods with broad global appeal. 
Table 1. Benefits and limitations of conventional breeding and agronomic biofortification approaches.

\begin{tabular}{|c|c|c|c|c|c|c|c|c|c|c|}
\hline \multirow[t]{2}{*}{ Approach } & \multicolumn{4}{|c|}{ Benefits } & \multicolumn{6}{|c|}{ Limitations } \\
\hline & Cost-Effective & Simple & Eco-Friendly & Timely & High-Cost & $\begin{array}{c}\text { Labor } \\
\text { Intensive }\end{array}$ & Unsustainable & $\begin{array}{c}\text { Time } \\
\text { Consuming }\end{array}$ & $\begin{array}{l}\text { Reliant on } \\
\text { Variation } 1\end{array}$ & $\begin{array}{l}\text { Environment- } \\
\text { Dependent }^{2}\end{array}$ \\
\hline $\begin{array}{l}\text { Conventional } \\
\text { Breeding } \\
\text { Agronomic } \\
\text { Inorganic } \\
\text { Fertilizers } \\
\text { Organic } \\
\text { Fertilizers }\end{array}$ & & & & & & & & & & \\
\hline Biofertilizers & & & & & & & & & & \\
\hline
\end{tabular}

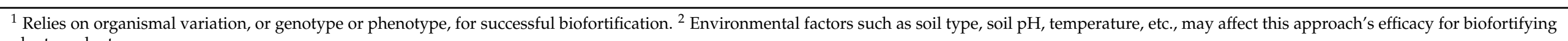
plant products. 


\section{Conventional Breeding}

Conventional plant breeding increases the essential nutrients of foods through the improvement of cultivars by the conservative manipulation of plant genomes within their natural genetic boundaries [23]. While conventional breeding has received less relative research attention than transgenic approaches to biofortify crops, as of 2018, it still has a higher success rate, with more released biofortified cultivars on a percentage basis [7]. Of those released cultivars, $58.1 \%$ have been cereals, followed by vegetables $(19.8 \%)$, legumes $(13.2 \%)$, and fruits (9\%) [7]. There are many methods for breeding biofortified crops without transgenic technologies such as single-seed descent, marker-selected-breeding, and genomic selection [23-25]. For instance, zinc biofortification of rice (Oryza sativa L.) has been facilitated through the identification of gene-specific markers and quantitative trait loci associated with increased grain zinc content [26,27].

Major research programs worldwide such as the European Union's Health Grain Project, the global HarvestPlus program, and the BioCassava Plus program have utilized conventional breeding to generate some of the most successful biofortified cultivars [7]. For instance, the biofortified, orange-fleshed sweet potato (Ipomoea batatas L.) cultivars were developed to comprise a greater content of $\beta$-carotene to help combat vitamin A deficiency in developing countries $[28,29]$. Nutritional analyses demonstrate that orange-fleshed sweet potato varieties contain up to 21 -fold more $\beta$-carotene than other sweet potato varieties [30]. Research has shown that the consumption of orange-fleshed sweet potato varieties alleviated vitamin A deficiency in children in Mozambique, Uganda, and South Africa [31-33]. Another prominent example is the iron-biofortified rice variety IR681442B-2-2-3, developed by the International Rice Research Institute in conjunction with the HarvestPlus program [34]. This rice variety contains four- to five-fold more iron after processing and cooking than other commercial rice varieties [34,35]. In a controlled diet study, this variety increased ferritin and whole-body iron by $20 \%$ in Filipino women [35]. For more examples of biofortified crops, please refer to the cited reviews $[3,6,7]$.

\subsection{Benefits of Conventional Breeding}

One of the major advantages of utilizing conventional breeding practices to biofortify foods is that the public widely accepts this process. Humans have been consciously and unconsciously altering domesticated plants for thousands of years, making this process a societal norm $[36,37]$. Therefore, biofortified foods developed by this process will be more likely accepted by a large portion of the world's population than food biofortified through transgenic approaches $[6,20]$. In addition to having a global appeal, this method is cost-effective for growers [6,38]. As mentioned above, micronutrient deficiencies occur mainly in vulnerable populations in developing regions such as Africa, Asia, and Latin America [1,2]. Most of the growers in these areas are smallholder farmers that generally live in poverty [39]. Unlike other biofortification processes, the biofortification of food through conventional breeding practices adds minimal additional costs to growers [40]. The majority of the costs associated with this practice would be incurred by the breeding institute through research and development of the biofortified cultivars [40].

Conventional breeding is also a more sustainable option for food biofortification than agronomic approaches $[6,8,41]$. As more research highlights the inadvertent negative effects of agricultural practices on the environment, the need to sustainably produce food has become more important than ever [42-45]. Specifically, the overuse of fertilizers in agroecosystems has been linked to algal blooms, reduced biodiversity, and polluted air and waterways [42-45]. In contrast, conventional breeding is considered a sustainable biofortification process, as it does not depend on the additional use of synthetic inputs in agroecosystems like some agronomic approaches.

\subsection{Limitations of Conventional Breeding}

Despite the numerous advantages of utilizing conventional breeding to biofortify foods, there are several limitations, the first of which is the reliance of this method on 
the standing diversity in the targeted crop gene pools. Biofortification can only occur if there is trait diversity present in the primary, secondary, or tertiary gene pool of the targeted crop [7,40]. If no diversity is present, then the targeted crop cannot be biofortified through conventional breeding. For example, oilseed biofortification has only occurred through transgenic processes due to its limited genetic diversity, low heritability, and linkage drag [7]. Additionally, ancillary gene pools that have been underutilized in crop improvement efforts may provide the greatest opportunity to identify lost beneficial nutritional traits [46-49]. For example, the stay-green phenotype in chickpeas (Cicer arietinum L.), a potentially lost trait as a result of domestication and breeding processes, was seen to be associated with greater levels of lutein and $\beta$-carotene when compared to conventional chickpea varieties [50]. Moreover, nutritional analyses of modern crops and their wild relatives revealed that some modern crops are of lower nutritional value than their wild counterparts [51-54]. Consequently, the wild relative gene pool may have potentially more beneficial phenotypes for biofortification than the domesticated gene pool $[48,49]$. However, the utilization of wild relatives could be a hurdle for several target crops due to pre- and post-zygotic reproductive barriers [55-58], the potential for unfavorable traits to be tightly linked to favorable traits $[59,60]$, and wild relatives being severely underrepresented in world gene banks [61]. The limited availability of wild accessions results from inadequate systematic collection of wild relatives in their native range. Furthermore, the current collection of wild relatives has become increasingly difficult due to the limited in situ conservation efforts placed on wild relatives. For example, 2 of 24 sites containing wild chickpea populations in southeastern Anatolia have been permanently lost due to rapid human development [47].

Another limitation of conventional breeding is that the process is rather timeconsuming [40,62]. It can take several years before a cultivar is deemed releasable by the breeding institute. This is because introgressing a trait into an elite cultivar requires extensive selection, at least until the sixth generation [62]. However, there are strategies such as high-throughput phenotyping platforms, seed chipping technology, molecular markers, genomic selecting breeding approaches, and the manipulation of day length that can expedite the release of a cultivar [62-64]. However, several of these methods have a higher upfront cost than traditional breeding methods. Thus, they are not widely utilized in some public breeding institutes even though they are more efficient on a per-dollar basis [64-67]. Moreover, before a cultivar is released, it needs to be tested in diverse growth environments, since genetic-by-environment interactions can substantially alter a crop's phenotype and potentially the nutritional components of the cultivar $[62,68,69]$. Therefore, due to genetic-by-environment interactions, a biofortified crop may lose its enhanced nutritional trait [68].

\section{Agronomic Biofortification Approaches}

Agronomic biofortification approaches are globally utilized because they are straightforward and timely. These approaches are defined as pre-harvest agronomic practices that enhance the nutritional content of food [70]. A caveat of these approaches is that they must occur pre-harvest for the food to be considered biofortified. If the approaches occur post-harvest, then the food is categorized as fortified [70]. Some agronomic biofortification practices are the application of soil or foliar inorganic fertilizers, organic fertilizers, and biofertilizer as well as nutri-priming.

The most prominent agronomic practices used to biofortify food crops are the soil or foliar application of inorganic fertilizers. The use of these fertilizers has resulted in enhanced micronutrient content for a variety of crops in various agroecosystems [7,71,72]. For instance, soil- or foliar-applied zinc fertilizers led to increased zinc content in corn (Zea mays L.) [73-77], wheat (Triticum aestivum L.) [72,76-79], peas (Pisum sativum L.) [80], chickpeas [81], potatoes (Solanum tuberosum L.) [82-84], and rice [85-89]. For more examples of crops biofortified through agronomic approaches, please refer to the cited reviews $[7,40,71,89,90]$. 
A similar method to applying fertilizers and foliar sprays with enhanced micronutrient content is the supplementation of micronutrient media to soilless cultivated food [91]. In soilless cultivation, plant productivity is optimized due to strictly regulated environmental conditions such as temperature, light, and nutrient solution $[92,93]$ and by maximizing root contact with the nutrient supply [94]. The constant root contact with the nutrient solution maximizes the uptake, translocation, and accumulation of micronutrients and allows for consistent crop nutritional quality [91,95]. In addition to these benefits, soilless cultivation extends the cultivation cycle and allows for year-round production due to, in part, the avoidance of soil limitations such as soil pollution, soil fertility reduction, and soil-borne diseases [91,96]. Furthermore, soilless cultivation has been described as having low labor requirements due to the absence of weeds, straightforward harvesting and processing, and the utilization of automated systems for plant care [96].

Research has shown that the supplementation of specific micronutrient media in soilless cultivation results in greater contents of folate in spinach (Spinacia oleracea L.) [97], silicon in green bean (Phaseolus vulgaris L.) [98], zinc and selenium in lettuce (Lactuca sativa L.) [99], and zinc in white cabbage (Brassica oleracea L.) [100]. Moreover, the role of microgreens as a soilless biofortified food product to combat micronutrient deficiencies, or as functional food, has become promising in recent years [101,102]. This is because microgreens have a high phytonutrient content, flavor-enhancing properties, a short cultivation cycle (harvested 7-21 days after germination), and can be biofortified through soilless cultivation [101,102]. For instance, the microgreens basil (Ocimum basilicum L.), coriander (Coriandrum sativum L.), and tatsoi (Brassica rapa subsp. narinosa (L.H. Bailey)) were biofortified with selenium [103,104], Brassicaceae microgreens with zinc and iron [105], and buckwheat microgreens (Fagopyrum esculentum (Moench)) with selenium and iodine [106]. Additionally, selenium biofortification of wheat microgreens has also led to increased levels of carotenoids or other bioactive compounds (phenolics, flavonoids, vitamin C, anthocyanin) [107]. More examples of biofortified food through soilless cultivation are specified in Rouphael et al. [91].

\subsection{Limitations of Inorganic Fertilizers to Biofortify Crops}

Although the application of inorganic fertilizers is an effective, relatively simple, and quick agronomic approach to biofortify crops in soil and soilless systems, there are several limitations to this approach. The primary limitations are the detrimental environmental effects that result from the overuse of inorganic fertilizers. As previously mentioned, the overuse of fertilizers in soil systems has led to water pollution, algal blooms, and a reduction in biodiversity in natural systems [52-55]. Moreover, inorganic fertilizers are expensive and labor-intensive to apply, which would add further financial strain to impoverished smallholder farmers, who make up a large portion of farmers in food-insecure areas [39]. Additionally, identifying when to apply fertilizers to achieve the maximum increase in nutrient content is another challenge [68,108,109]. Phattarakul et al. [101] found that foliar zinc application to rice after flowering, during the early milk plus dough stages, increased grain zinc content more than earlier applications [108]. However, Rodrigo et al. [102] found that foliar selenium application to wheat pre-flowering and in between the booting and heading stages increased selenium grain content the most [109].

Furthermore, similar to soil cultivation practices, the timing, chemical form, and amount of fertilizers in soilless cultivation are critical for effective biofortification [91]. For instance, when comparing carrots (Daucus carota subsp. sativus (Hoffm.)) biofortified hydroponically to field foliar fertilizer applications, the same rate of iodine fertilization resulted in cumulative toxic levels of iodine in the hydroponically biofortified carrots [110]. Moreover, the biofortification of multiple micronutrients at once may be problematic in soilless cultivation due to the potential antagonistic effects micronutrients have on crop accumulation. Germ et al. [96] found that selenium content was greatest in buckwheat when fertilized in combination with selenium and iodine; however, iodine content was greatest when fertilized with iodine alone [106]. Therefore, for fertilization to be an effective 
and efficient soil and soilless biofortification approach, the proper timing, amount, and chemical form of the application are critical.

Furthermore, crop phenotype, genotype, and soil conditions are additional factors that influence the effectiveness of fertilizers to biofortify crops [111,112]. It has been documented that phenotypic differences in nutrient uptake, translocation, and accumulation result from plant genotype [112-114]. For example, rice [68,115] and corn [74] genotypes differed in grain zinc content when applied with zinc fertilizers. Additionally, soil factors can exacerbate nutrient accumulation differences between genotypes. Mabesa et al. [68] showed that only one out of the eight tested rice biofortification breeding lines reached the targeted zinc concentration when grown in a severe zinc-deficient site with fertilization [68]. Likewise, iron biofortification via iron fertilization of calcareous soil with high $\mathrm{pH}$ is ineffective due to the reduced mobility of iron and the rapid conversion of iron into unavailable forms [116]. Therefore, crop genotype and the growth environment can severely hinder the biofortification of crops with fertilizers. Detailed mechanisms of how plants uptake, translocate, and accumulate micronutrients can be found in White and Broadley [112]. This limitation is less pronounced in soilless systems, as environmental conditions in these systems can be tailored to any crop genotype. However, soilless biofortification has several unique limitations: It is considered expensive due to the necessary equipment and energy costs [117], is not applicable to all crop types, is considered unsustainable in some regions [117], and is limited in capacity due to the physical constraints of the soilless system being used (e.g., size of the greenhouse, pots, etc.).

\subsection{Benefits and Limitations of Other Agronomic Approaches}

Other agronomic approaches to biofortify crops include the application of organic fertilizers. Organic fertilizers have been categorized as a cost-effective, eco-friendly alternative to inorganic synthetic fertilizers [118-122]. Organic fertilizers are obtained from animal or plant sources such as animal manure or green manure, respectively, and have been shown to increase the micronutrient content in various crops [121,123,124]. For example, vermicompost (earthworms converting organic waste into fertilizer) increased the content of zinc by $14 \%$ and iron by $7 \%$ in barley (Hordeum vulgare L.) [125], and poultry manure increased the iron content in wheat by 15\% [126] and in rice by $10 \%$ [127]. However, if not properly treated, a major disadvantage of some organic fertilizers is that they may contain human pathogens such as Escherichia coli, antibiotics, and heavy metals [128,129]. Additionally, organic fertilizers are considered an imprecise method to provide nutrients to crops because the nutrient content in organic fertilizers is highly variable, and when applied, the nutrients are not immediately available to the crops [122,130]. The amount of nutrients and the element types in organic fertilizers are mainly dependent on the age, origin (animal or plant), and environmental conditions from which the organic fertilizers were derived [130].

Biofertilizers differ from organic and inorganic fertilizers as they are substances that contain microbial inoculants, consisting of microorganisms that promote the growth and productivity of the host plant $[118,119]$. These bacteria are commonly referred to as plant growth-promoting bacteria. In addition to enhanced growth, these bacteria have also been shown to augment the nutrient content in crops by increasing the supply or availability of nutrients [118,119]. Specific biofertilizers such as cyanobacteria (Anabaena Azotobacter sp. Biofilm and Anabaena sp.-viz. Providencia sp) and Bacillus aryabhattai facilitated the zinc biofortification of corn [131], wheat [132], and soybeans (Glycine max L.) [132], respectively. Despite this practical promise, biofertilizers have not been shown to offset the use of fertilizers in agroecosystems due to several obstacles [133], one of which is the identification of the proper plant growth-promoting bacterium for each host crop, particularly one that can withstand packaging, storage, and application on a global scale [133]. Furthermore, the beneficial effects that biofertilizers may provide may be short-lived due to the agroecosystem's environment. This is because environmental factors such as soil $\mathrm{pH}$ have a more substantial influence on the presence of soil microorganisms 
than the host plant $[134,135]$. Consequently, there is the potential that the supplied plantgrowth-promoting bacteria may be maladapted to the environment, resulting in minimal crop biofortification.

Another biofortification approach is nutri-priming, which is the method of soaking seeds in solutions containing nutrients before planting [136-138]. Nutri-priming has been primarily used for yield improvement, germination, seedling establishment, and root system development in crops [136-138]. However, some studies have shown that this process improves grain nutrient content $[138,139]$. For instance, zinc nutri-priming increased grain zinc content by $29 \%$ in chickpeas [140] and from $12 \%$ to $15 \%$ in wheat $[140,141]$. Furthermore, nutri-priming flax and fenugreek with fish oil increased polyunsaturated essential fatty acids (i.e., docosahexaenoic acid and eicosapentaenoic acid) in sprouts [142]. An additional benefit of nutri-priming is that farmers can conduct this approach, as it is considered a low-cost and simple practice for nutrient enrichment [81,140]. However, the effectiveness of nutri-priming may be largely affected by crop type, genotype, time (duration of the priming process), osmotic potential of the priming solution, and environmental conditions (e.g., light and temperature) $[136,137,143]$.

\section{Conclusions}

Biofortification of food through conventional breeding and agronomic approaches has been successful for various crops. As a result, biofortified food has enhanced nutrient concentration in diets, which benefits human health in food-insecure areas. However, there are several limitations to conventional breeding and agronomic approaches such as the detrimental effects of fertilizers on the environment, if misused, or the limited genetic variation present in some crops. These limitations dampen the efficacy and application of biofortification methods globally. Nonetheless, the first step in overcoming the described hurdles is identifying alternative practices, and critical research is required to broaden the applicability of biofortification approaches. However, if the efficacy and application of biofortification does increase, biofortification alone is not the sole answer to providing relief for the two billion people worldwide suffering from hidden hunger. Biofortification as a whole has limitations. In particular, the process does not address the high cost or accessibility of micronutrient-rich foods. Additionally, biofortified foods are generally limited in the amount and range of micronutrients [4]. Therefore, an assortment of intervention approaches, such as diversifying diets and the fortification of commercial food along with biofortification, will need to be utilized to help alleviate hidden hunger.

Author Contributions: Conceptualization, E.M. and J.K.; Writing-Original Draft Preparation E.M.; Writing-review \& editing E.M., J.K., H.M.D., Visualization, E.M.; Supervision, J.K. and H.M.D.; Project Administration, J.K. and H.M.D.; Funding Acquisition, J.K. and H.M.D. All authors have read and agreed to the published version of the manuscript.

Funding: This research was supported by UVM Ventures: Vermont Dept. of Economic Development \#07120-19-17.

Institutional Review Board Statement: Not applicable.

Informed Consent Statement: Not applicable.

Data Availability Statement: Data sharing not applicable.

Acknowledgments: We would like to thank Erika Bueno and Allison Unger for their help with the preparation of the manuscript and Jorge Ruiz-Arocho for illustrating Figure 1.

Conflicts of Interest: Authors declare no conflicts of interest.

\section{References}

1. Food and Agriculture Organization. The Future of Food and Agriculture, Trends and Challenges; Food and Agriculture Organization: Rome, Italy, 2017; Volume 4, ISBN 9789251095515.

2. Food and Agriculture Organization (FAO). The State of Food and Agriculture-Executive Summary; FAO: Rome, Italy, 2013.

3. Pfeiffer, W.H.; McClafferty, B. HarvestPlus: Breeding crops for better nutrition. Crop. Sci. 2007, 47, S-88. [CrossRef] 
4. Saltzman, A.; Birol, E.; Wiesman, D.; Prasai, N.; Yohannes, Y.; Menon, P.; Thompson, J. 2014 Global Hunger Index: The Challenge of Hidden Hunger; Welthungerhilfe International Food Policy Research Institute (IFPRI) Concern Worldwide: Bonn, Germany; Washington, DC, USA; Dublin, Ireland, 2014.

5. Bailey, R.L.; West, K.P.; Black, R.E. The epidemiology of global micronutrient deficiencies. Ann. Nutr. Metab. 2015, 66, 22-33. [CrossRef]

6. Bouis, H.E.; Saltzman, A. Improving nutrition through biofortification: A review of evidence from HarvestPlus, 2003 through 2016. Glob. Food Secur. 2017, 12, 49-58. [CrossRef] [PubMed]

7. Garg, M.; Sharma, N.; Sharma, S.; Kapoor, P.; Kumar, A.; Chunduri, V.; Arora, P. Biofortified Crops Generated by Breeding, Agronomy, and Transgenic Approaches Are Improving Lives of Millions of People around the World. Front. Nutr. 2018, 5, 12. [CrossRef] [PubMed]

8. Bouis, H.E.; Welch, R.M. Biofortification-A sustainable agricultural strategy for reducing micronutrient malnutrition in the global south. Crop. Sci. 2010, 50, S-20-S-32. [CrossRef]

9. Siró, I.; Kápolna, E.; Kápolna, B.; Lugasi, A. Functional food. Product development, marketing and consumer acceptance-A review. Appetite 2008, 51, 456-467. [CrossRef]

10. Szakály, Z.; Szente, V.; Kövér, G.; Polereczki, Z.; Szigeti, O. The influence of lifestyle on health behavior and preference for functional foods. Appetite 2012, 58, 406-413. [CrossRef]

11. Szakály, Z.; Kovács, S.; Pető, K.; Huszka, P.; Kiss, M. A modified model of the willingness to pay for functional foods. Appetite 2019, 138, 94-101. [CrossRef]

12. Pappalardo, G.; Lusk, J.L. The role of beliefs in purchasing process of functional foods. Food Qual. Prefer. 2016, 53, 151-158. [CrossRef]

13. Vicentini, A.; Liberatore, L.; Mastrocola, D. Functional Foods: Trends and Development. Ital. J. Food Sci. $2016,28,338-352$.

14. Morris, D. Description and composition of flax. In Flax-A Health and Nutrition Primer; Flax Council of Canada: Winnipeg, MB, Canada, 2007; pp. 9-21.

15. Flax Council of Canada. Chapter 11: Varieties Varietal Development in Canada Three. In Growing Flax Production, Management and Diagnostic Guide; Flax Council of Canada: Winnipeg, MB, Canada, 2015; pp. 49-53.

16. Precedence Research. Functional Food Market Size, Share, Growth, Trends, Consumption, Regional Insights and Forecast 2020 to 2027; Precedence Research: Ottawa, ON, Canada, 2020.

17. Scott, S.E.; Inbar, Y.; Rozin, P. Evidence for Absolute Moral Opposition to Genetically Modified Food in the United States. Perspect. Psychol. Sci. 2016, 11, 315-324. [CrossRef]

18. Frewer, L.J.; van der Lans, I.A.; Fischer, A.R.H.; Reinders, M.J.; Menozzi, D.; Zhang, X.; van den Berg, I.; Zimmermann, K.L. Public perceptions of agri-food applications of genetic modification-A systematic review and meta-analysis. Trends Food Sci. Technol. 2013, 30, 142-152. [CrossRef]

19. Shew, A.M.; Nalley, L.L.; Snell, H.A.; Nayga, R.M.; Dixon, B.L. CRISPR versus GMOs: Public acceptance and valuation. Glob. Food Secur. 2018, 19, 71-80. [CrossRef]

20. Lucht, J.M. Public acceptance of plant biotechnology and GM crops. Viruses 2015, 7, 4254-4281. [CrossRef] [PubMed]

21. Funk, B.Y.C.; Kennedy, B. The New Food Fights: US Public Divides over Food Science; Pew Research Center: Washington, DC, USA, 2016.

22. Mabaya, E.; Fulton, J.; Simiyu-Wafukho, S.; Nang'ayo, F. Factors influencing adoption of genetically modified crops in Africa. Dev. South. Afr. 2015, 32, 577-591. [CrossRef]

23. Acquaah, G. Conventional plant breeding principles and techniques. In Advances in Plant Breeding Strategies: Breeding, Biotechnology and Molecular Tools; Al-Khayri, J., Jain, S., Johnson, D., Eds.; Springer: Cham, Switzerland, 2015; Volume 1, pp. 115-158. ISBN 9783319225210 .

24. Jiang, G.-L. Molecular Markers and Marker-Assisted Breeding in Plants in Plant Breeding from Laboratories to Fields. In Intech; Intech Open: London, UK, 2013.

25. Breseghello, F.; Coelho, A.S.G. Traditional and modern plant breeding methods with examples in rice (Oryza sativa L.). J. Agric. Food Chem. 2013, 61, 8277-8286. [CrossRef]

26. Mahender, A.; Anandan, A.; Pradhan, S.K.; Pandit, E. Rice grain nutritional traits and their enhancement using relevant genes and QTLs through advanced approaches. Springerplus 2016, 5, 1-18. [CrossRef] [PubMed]

27. Swamy, B.P.M.; Rahman, M.A.; Inabangan-Asilo, M.A.; Amparado, A.; Manito, C.; Chadha-Mohanty, P.; Reinke, R.; Slamet-Loedin, I.H. Advances in breeding for high grain Zinc in Rice. Rice 2016, 9, 1-16. [CrossRef]

28. International Potato Center. Sweetpotato Agri-Food Systems Program; International Potato Center: Lima, Peru, 2019.

29. Low, J.W.; Mwanga, R.O.M.; Andrade, M.; Carey, E.; Ball, A.M. Tackling vitamin A deficiency with biofortified sweetpotato in sub-Saharan Africa. Glob. Food Secur. 2017, 14, 23-30. [CrossRef]

30. Huang, A.S.; Tanudjaja, L.; Lum, D. Content of Alpha-, Beta-Carotene, and Dietary Fiber in 18 Sweetpotato Varieties Grown in Hawaii. J. Food Compos. Anal. 1999, 12, 147-151. [CrossRef]

31. Hotz, C.; Loechl, C.; Lubowa, A.; Tumwine, J.K.; Masawi, G.N.; Baingana, R.; Carriquiry, A.; de Brauw Meenakshi, A.; Gilligan, D.O. Introduction of $\beta$-Carotene-Rich orange sweet potato in rural Uganda resulted in increased vitamin a intakes among children and women and improved vitamin a status among children. J. Nutr. 2012, 142, 1871-1880. [CrossRef] [PubMed] 
32. Hotz, C.; Loechl, C.; De Brauw, A.; Eozenou, P.; Gilligan, D.; Moursi, M.; Munhaua, B.; Van Jaarsveld, P.; Carriquiry, A.; Meenakshi, J.V. A large-scale intervention to introduce orange sweet potato in rural Mozambique increases vitamin A intakes among children and women. Br. J. Nutr. 2012, 108, 163-176. [CrossRef]

33. Van Jaarsveld, P.J.; Faber, M.; Tanumihardjo, S.A.; Nestel, P.; Lombard, C.J.; Benadé, A.J.S. $\beta$-carotene-rich orange-fleshed sweet potato improves the vitamin A status of primary school children assessed with the modified-relative-dose-response test. Am. J. Clin. Nutr. 2005, 81, 1080-1087. [CrossRef]

34. Gregorio, G.B.; Senadhira, D.; Htut, H.; Graham, R.D. Breeding for trace minerals in rice. Food Nutr. Bull. 2000, 21, 382-396. [CrossRef]

35. Haas, J.D.; Beard, J.L.; Murray-Kolb, L.E.; Del Mundo, A.M.; Felix, A.; Gregorio, G.B. Iron-biofortified rice improves the iron stores of nonanemic filipino women. J. Nutr. 2005, 135, 2823-2830. [CrossRef]

36. Doebley, J.F.; Gaut, B.S.; Smith, B.D. The Molecular Genetics of Crop Domestication. Cell 2006, 127, 1309-1321. [CrossRef]

37. Meyer, R.S.; Duval, A.E.; Jensen, H.R. Patterns and processes in crop domestication: An historical review and quantitative analysis of 203 global food crops. New Phytol. 2012, 196, 29-48. [CrossRef]

38. Meenakshi, J.V.; Johnson, N.L.; Manyong, V.M.; De Groote, H.; Javelosa, J.; Yanggen, D.R.; Naher, F.; Gonzalez, C.; García, J.; Meng, E. How Cost-Effective is Biofortification in Combating Micronutrient Malnutrition? An Ex ante Assessment. World Dev. 2010, 38, 64-75. [CrossRef]

39. FAOSTAT. Food and Agricultural Commodities Production. Available online: http://www.faostat.fao.org (accessed on 12 January 2021).

40. Jha, A.B.; Warkentin, T.D. Biofortification of pulse crops: Status and future perspectives. Plants 2020, 9, 73. [CrossRef]

41. Welch, R.M. Breeding strategies for biofortified staple plant foods to reduce micronutrient malnutrition globally. J. Nutr. 2002, 132, 495-499. [CrossRef] [PubMed]

42. Brodt, S.; Six, J.; Feenstra, G.; Ingels, C.; Campbell, D. Sustainable Agriculture. Nat. Educ. Knowl. $2011,3,1$.

43. Hart, M.R.; Quin, B.F.; Nguyen, M.L. Phosphorus Runoff from Agricultural Land and Direct Fertilizer Effects: A Review. J. Environ. Qual. 2004, 33, 1954-1972. [CrossRef] [PubMed]

44. McLaughlin, A.; Mineau, P. The impact of agricultural practices on biodiversity. Agric. Ecosyst. Environ. 1995, 55, $201-212$. [CrossRef]

45. Stoate, C.; Báldi, A.; Beja, P.; Boatman, N.D.; Herzon, I.; van Doorn, A.; de Snoo, G.R.; Rakosy, L.; Ramwell, C. Ecological impacts of early 21st century agricultural change in Europe-A review. J. Environ. Manag. 2009, 91, 22-46. [CrossRef]

46. Warschefsky, E.; Penmetsa, R.V.; Cook, D.R.; Von Wettberg, E.J.B. Back to the wilds: Tapping evolutionary adaptations for resilient crops through systematic hybridization with crop wild relatives. Am. J. Bot. 2014, 101, 1791-1800. [CrossRef] [PubMed]

47. Von Wettberg, E.J.B.; Chang, P.L.; Başdemir, F.; Carrasquila-Garcia, N.; Korbu, L.B.; Moenga, S.M.; Bedada, G.; Greenlon, A.; Moriuchi, K.S.; Singh, V.; et al. Ecology and genomics of an important crop wild relative as a prelude to agricultural innovation. Nat. Commun. 2018, 9, 649. [CrossRef] [PubMed]

48. Coyne, C.J.; Kumar, S.; Wettberg, E.J.B.; Marques, E.; Berger, J.D.; Redden, R.J.; Ellis, T.H.N.; Brus, J.; Zablatzká, L.; Smýkal, P. Potential and limits of exploitation of crop wild relatives for pea, lentil, and chickpea improvement. Legum. Sci. 2020, 2. [CrossRef]

49. Brozynska, M.; Furtado, A.; Henry, R.J. Genomics of crop wild relatives: Expanding the gene pool for crop improvement. Plant Biotechnol. J. 2016, 14, 1070-1085. [CrossRef]

50. Sivasakthi, K.; Marques, E.; Kalungwana, N.; Cordeiro, M.; Sani, S.G.A.S.; Udupa, S.M.; Rather, I.A.; Mir, R.R.; Vadez, V.; Vandemark, G.J.; et al. Functional Dissection of the Chickpea (Cicer arietinum L.) Stay-Green Phenotype Associated with Molecular Variation at an Ortholog of Mendel's I Gene for Cotyledon Color: Implications for Crop Production and Carotenoid Biofortification. Int. J. Mol. Sci. 2019, 20, 5562. [CrossRef] [PubMed]

51. Fernández-marín, B.; Milla, R.; Martín-robles, N.; Arc, E.; Kranner, I.; Becerril, J.M.; García-plazaola, J.I. Side-effects of domestication: Cultivated legume seeds contain similar tocopherols and fatty acids but less carotenoids than their wild counterparts. BMC Plant Biol. 2014, 14, 1599. [CrossRef]

52. Fernández-Ruiz, V.; Olives, A.I.; Cámara, M.; Sánchez-Mata, M.D.C.; Torija, M.E. Mineral and trace elements content in 30 accessions of tomato fruits (Solanum lycopersicum L.) and wild relatives (Solanum pimpinellifolium L., Solanum cheesmaniae L. Riley, and Solanum habrochaites S. Knapp \& D.M. Spooner). Biol. Trace Elem. Res. 2011, 141, 329-339. [CrossRef]

53. Zhang, H.; Yasmin, F.; Song, B.H. Neglected treasures in the wild-Legume wild relatives in food security and human health. Curr. Opin. Plant Biol. 2019, 49, 17-26. [CrossRef]

54. Schier, H.E.; Eliot, K.A.; Herron, S.A.; Landfried, L.K.; Migicovsky, Z.; Rubin, M.J.; Miller, A.J. Comparative analysis of perennial and annual Phaseolus seed nutrient concentrations. Sustainability 2019, 11, 2787. [CrossRef]

55. Jewell, C.P.; Zhang, S.V.; Gibson, M.J.S.; Tovar-Méndez, A.; Mcclure, B.; Moyle, L.C. Intraspecific Genetic Variation Underlying Postmating Reproductive Barriers between Species in the Wild Tomato Clade (Solanum sect. Lycopersicon). J. Hered. 2020, 111, 216-226. [CrossRef]

56. Dempewolf, H.; Hodgins, K.A.; Rummell, S.E.; Ellstrand, N.C.; Rieseberg, L.H. Reproductive isolation during domestication. Plant Cell 2012, 24, 2710-2717. [CrossRef]

57. Munguía-Rosas, M.A.; Jácome-Flores, M.E. Reproductive isolation between wild and domesticated chaya (Cnidoscolus aconitifolius) in sympatry. Plant Biol. 2020, 22, 932-938. [CrossRef] 
58. Greene, S.L.; Williams, K.A.; Khoury, C.K.; Kantar, M.B.; Marek, L.F. North American crop wild relatives: Conservation strategies. North Am. Crop Wild Relat. Conserv. Strateg. 2018, 1, 1-346. [CrossRef]

59. Varshney, R.K.; Terauchi, R.; McCouch, S.R. Harvesting the Promising Fruits of Genomics: Applying Genome Sequencing Technologies to Crop Breeding. PLoS Biol. 2014, 12, e1001883. [CrossRef] [PubMed]

60. Li, D.; Pfeiffer, T.W.; Cornelius, P.L. Soybean QTL for yield and yield components associated with Glycine soja alleles. Crop Sci. 2008, 48, 571-581. [CrossRef]

61. Castañeda-Álvarez, N.P.; Khoury, C.K.; Achicanoy, H.A.; Bernau, V.; Dempewolf, H.; Eastwood, R.J.; Guarino, L.; Harker, R.H.; Jarvis, A.; Maxted, N.; et al. Global conservation priorities for crop wild relatives. Nat. Plants 2016, 2, 1-6. [CrossRef]

62. Glenn, K.C.; Alsop, B.; Bell, E.; Goley, M.; Jenkinson, J.; Liu, B.; Martin, C.; Parrott, W.; Souder, C.; Sparks, O.; et al. Bringing new plant varieties to market: Plant breeding and selection practices advance beneficial characteristics while minimizing unintended changes. Crop Sci. 2017, 57, 2906-2921. [CrossRef]

63. Ghosh, S.; Watson, A.; Gonzalez-Navarro, O.E.; Ramirez-Gonzalez, R.H.; Yanes, L.; Mendoza-Suárez, M.; Simmonds, J.; Wells, R.; Rayner, T.; Green, P.; et al. Speed breeding in growth chambers and glasshouses for crop breeding and model plant research. bioRxiv 2018, 13, 369512. [CrossRef]

64. Ahmar, S.; Gill, R.A.; Jung, K.H.; Faheem, A.; Qasim, M.U.; Mubeen, M.; Zhou, W. Conventional and molecular techniques from simple breeding to speed breeding in crop plants: Recent advances and future outlook. Int. J. Mol. Sci. 2020, 21, 2590. [CrossRef]

65. Heffner, E.L.; Lorenz, A.J.; Jannink, J.L.; Sorrells, M.E. Plant breeding with Genomic selection: Gain per unit time and cost. Crop Sci. 2010, 50, 1681-1690. [CrossRef]

66. Gorjanc, G.; Battagin, M.; Dumasy, J.F.; Antolin, R.; Gaynor, R.C.; Hickey, J.M. Prospects for cost-effective genomic selection via accurate within-family imputation. Crop Sci. 2017, 57, 216-228. [CrossRef]

67. Xu, Y.; Liu, X.; Fu, J.; Wang, H.; Wang, J.; Huang, C.; Prasanna, B.M.; Olsen, M.S.; Wang, G.; Zhang, A. Enhancing Genetic Gain through Genomic Selection: From Livestock to Plants. Plant Commun. 2020, 1, 100005. [CrossRef]

68. Mabesa, R.L.; Impa, S.M.; Grewal, D.; Johnson-Beebout, S.E. Contrasting grain-Zn response of biofortification rice (Oryza sativa L.) breeding lines to foliar Zn application. Field Crop. Res. 2013, 149, 223-233. [CrossRef]

69. Bressan, E.A.; de Carvalho, I.A.S.; Borges, M.T.M.R.; da Carneiro, M.S.; Silva, E.F.; Gazaffi, R.; Shirasuna, R.T.; Abreu, V.; Popin, R.V.; Figueira, A.; et al. Assessment of Gene Flow to Wild Relatives and Nutritional Composition of Sugarcane in Brazil. Front. Bioeng. Biotechnol. 2020, 8, 1-14. [CrossRef]

70. World Health Organization. Bifortification of Staple Crops. Available online: http://www.who.int/elena/titles/complementary_ feeding/en/ (accessed on 12 January 2021).

71. Hirschi, K.D. Nutrient biofortification of food crops. Annual Rev. Nutr. 2009, 29, 401-421. [CrossRef] [PubMed]

72. Zou, C.Q.; Zhang, Y.Q.; Rashid, A.; Ram, H.; Savasli, E.; Arisoy, R.Z.; Ortiz-Monasterio, I.; Simunji, S.; Wang, Z.H.; Sohu, V.; et al. Biofortification of wheat with zinc through zinc fertilization in seven countries. Plant Soil 2012, 361, 119-130. [CrossRef]

73. Zhang, Y.Q.; Pang, L.L.; Yan, P.; Liu, D.Y.; Zhang, W.; Yost, R.; Zhang, F.S.; Zou, C.Q. Zinc fertilizer placement affects zinc content in maize plant. Plant Soil 2013, 372, 81-92. [CrossRef]

74. Fahad, S.; Hussain, S.; Saud, S.; Hassan, S.; Shan, D.; Chen, Y.; Deng, N.; Khan, F.; Wu, C.; Wu, W.; et al. Grain Cadmium and Zinc Concentrations in Maize Influenced by Genotypic Variations and Zinc Fertilization. Clean Soil Air Water 2015, 43, 1433-1440. [CrossRef]

75. Maqbool, M.A.; Beshir, A.R. Zinc biofortification of maize (Zea mays L.): Status and challenges. Plant Breed. 2019, 138, 1-28. [CrossRef]

76. Cakmak, I.; Kutman, U.B. Agronomic biofortification of cereals with zinc: A review. Eur. J. Soil Sci. 2018, 69, 172-180. [CrossRef]

77. Wang, J.; Mao, H.; Zhao, H.; Huang, D.; Wang, Z. Different increases in maize and wheat grain zinc concentrations caused by soil and foliar applications of zinc in Loess Plateau, China. Field Crop. Res. 2012, 135, 89-96. [CrossRef]

78. Yang, X.; Tian, X.; Gale, W.; Cao, Y.; Lu, X.; Zhao, A. Effect of soil and foliar zinc application on zinc concentration and bioavailability in wheat grain grown on potentially zinc-deficient soil. Cereal Res. Commun. 2011, 39, 535-543. [CrossRef]

79. Zou, C.; Du, Y.; Rashid, A.; Ram, H.; Savasli, E.; Pieterse, P.J.; Ortiz-Monasterio, I.; Yazici, A.; Kaur, C.; Mahmood, K.; et al. Simultaneous Biofortification of Wheat with Zinc, Iodine, Selenium, and Iron through Foliar Treatment of a Micronutrient Cocktail in Six Countries. J. Agric. Food Chem. 2019, 67, 8096-8106. [CrossRef]

80. Poblaciones, M.J.; Rengel, Z. Soil and foliar zinc biofortification in field pea (Pisum sativum L.): Grain accumulation and bioavailability in raw and cooked grains. Food Chem. 2016, 212, 427-433. [CrossRef] [PubMed]

81. Shivay, Y.S.; Singh, U.; Prasad, R.; Kaur, R. Agronomic interventions for micronutrient biofortification of pulses. Indian J. Agron. 2016, 61, 161-172.

82. White, P.J.; Broadley, M.R.; Hammond, J.P.; Ramsay, G.; Subramanian, N.K.; Thompson, J.; Wright, G. Bio-fortification of potato tubers using foliar zinc-fertiliser. J. Hortic. Sci. Biotechnol. 2012, 87, 123-129. [CrossRef]

83. White, P.J.; Thompson, J.A.; Wright, G.; Rasmussen, S.K. Biofortifying Scottish potatoes with zinc. Plant Soil 2017, 411, 151-165. [CrossRef]

84. Kromann, P.; Valverde, F.; Alvarado, S.; Vélez, R.; Pisuña, J.; Potosí, B.; Taipe, A.; Caballero, D.; Cabezas, A.; Devaux, A. Can Andean potatoes be agronomically biofortified with iron and zinc fertilizers? Plant Soil 2017, 411, 121-138. [CrossRef]

85. Wei, Y.; Shohag, M.J.I.; Yang, X. Biofortification and Bioavailability of Rice Grain Zinc as Affected by Different Forms of Foliar Zinc Fertilization. PLoS ONE 2012, 7, e45428. [CrossRef] 
86. Guo, J.X.; Feng, X.M.; Hu, X.Y.; Tian, G.L.; Ling, N.; Wang, J.H.; Shen, Q.R.; Guo, S.W. Effects of soil zinc availability, nitrogen fertilizer rate and zinc fertilizer application method on zinc biofortification of rice. J. Agric. Sci. 2016, 154, 584-597. [CrossRef]

87. Boonchuay, P.; Cakmak, I.; Rerkasem, B.; Prom-U-Thai, C. Effect of different foliar zinc application at different growth stages on seed zinc concentration and its impact on seedling vigor in rice. Soil Sci. Plant Nutr. 2013, 59, 180-188. [CrossRef]

88. Ram, H.; Rashid, A.; Zhang, W.; Duarte, A.P.; Phattarakul, N.; Simunji, S.; Kalayci, M.; Freitas, R.; Rerkasem, B.; Bal, R.S.; et al. Biofortification of wheat, rice and common bean by applying foliar zinc fertilizer along with pesticides in seven countries. Plant Soil 2016, 403, 389-401. [CrossRef]

89. Nakandalage, N.; Nicolas, M.; Norton, R.M.; Hirotsu, N.; Milham, P.J.; Seneweera, S. Improving rice zinc biofortification success rates through genetic and crop management approaches in a changing environment. Front. Plant Sci. 2016, 7, 1-13. [CrossRef]

90. Lupwayi, N.Z.; Rice, W.A.; Clayton, G.W. Soil microbial diversity and community structure under wheat as influenced by tillage and crop rotation. Soil Biol. Biochem. 1998, 30, 1733-1741. [CrossRef]

91. Rouphael, Y.; Kyriacou, M.C. Enhancing Quality of Fresh Vegetables through Salinity Eustress and Biofortification Applications Facilitated by Soilless Cultivation. Front. Plant Sci. 2018, 9, 1-6. [CrossRef]

92. Gruda, N. Impact of environmental factors on product quality of greenhouse vegetables for fresh consumption. Crit. Rev. Plant Sci. 2005, 24, 227-247. [CrossRef]

93. Gruda, N. Do soilless culture systems have an influence on product quality of vegetables? J. Appl. Bot. Food Qual. 2009, $82,141-147$.

94. Treftz, C.; Omaye, S.T. Hydroponics: Potential for augmenting sustainable food production in non-arable regions. Nutr. Food Sci. 2016, 46, 672-684. [CrossRef]

95. Wiesner-Reinhold, M.; Schreiner, M.; Baldermann, S.; Schwarz, D.; Hanschen, F.S.; Kipp, A.P.; Rowan, D.D.; Bentley-Hewitt, K.L.; McKenzie, M.J. Mechanisms of selenium enrichment and measurement in brassicaceous vegetables, and their application to human health. Front. Plant Sci. 2017, 8, 1365. [CrossRef]

96. Tomasi, N.; Pinton, R.; Dalla, L.; Cortella, G.; Terzano, R.; Mimmo, T.; Scampicchio, M.; Cesco, S. Trends in Food Science \& Technology New 'solutions' for floating cultivation system of ready-to-eat salad: A review. Trends Food Sci. Technol. 2015, 46, 267-276. [CrossRef]

97. Watanabe, S.; Ohtani, Y.; Tatsukami, Y.; Aoki, W.; Amemiya, T.; Sukekiyo, Y.; Kubokawa, S.; Ueda, M. Folate Biofortification in Hydroponically Cultivated Spinach by the Addition of Phenylalanine. J. Agric. Food Chem. 2017, 65, 4605-4610. [CrossRef]

98. Montesano, F.F.; Imp, M.D.; Parente, A.; Car, A.; Renna, M.; Serio, F. Green bean biofortification for Si through soilless cultivation: Plant response and Si bioaccessibility in pods. Sci. Rep. 2016, 6, 31662. [CrossRef] [PubMed]

99. Sahin, O. Combined biofortification of soilless grown lettuce with iodine, selenium and zinc and its effect on essential and non-essential elemental composition. J. Plant Nutr. 2020, 44, 673-678. [CrossRef]

100. Barrameda-Medina, Y.; Blasco, B.; Lentini, M.; Esposito, S.; Baenas, N.; Moreno, D.A.; Ruiz, J.M. Zinc biofortification improves phytochemicals and amino-acidic profile in Brassica oleracea cv. Bronco. Plant Sci. 2017, 258, 45-51. [CrossRef]

101. Kyriacou, M.C.; Rouphael, Y.; Di, F.; Kyratzis, A.; Serio, F.; Renna, M.; De Pascale, S.; Santamaria, P. Micro-scale vegetable production and the rise of microgreens. Trends Food Sci. Technol. 2016, 57, 103-115. [CrossRef]

102. Xiao, Z.; Lester, G.E.; Luo, Y.; Wang, Q. Assessment of Vitamin and Carotenoid Concentrations of Emerging Food Products: Edible Microgreens. J. Agric. Food Chem. 2012, 60, 7644-7651. [CrossRef]

103. Puccinelli, M.; Malorgio, F.; Rosellini, I.; Pezzarossa, B. Production of selenium-biofortified microgreens from selenium-enriched seeds of basil. J. Sci. Food Agric. 2019, 99, 5601-5605. [CrossRef]

104. Pannico, A.; El-Nakhel, C.; Graziani, G.; Kyriacou, M.C.; Giordano, M.; Soteriou, G.A.; Zarrelli, A.; Ritieni, A.; De Pascale, S.; Rouphael, Y. Selenium Biofortification Impacts the Nutritive Value, Polyphenolic Content, and Bioactive Constitution of Variable Microgreens Genotypes. Antioxidants 2020, 9, 272. [CrossRef] [PubMed]

105. Di Gioia, F.; Petropoulos, S.A.; Ozores-hampton, M.; Morgan, K.; Rosskopf, E.N. Zinc and Iron Agronomic Biofortification of Brassicaceae Microgreens. Agronomy 2019, 9, 677. [CrossRef]

106. Germ, M.; Stibilj, V.; Šircelj, H.; Jerše, A. Biofortification of common buckwheat microgreens and seeds with different forms of selenium and iodine. J. Sci. Food Agric. 2019, 99, 4353-4362. [CrossRef] [PubMed]

107. Zahirul, M.; Park, B.; Kang, H.; Lee, Y. Influence of selenium biofortification on the bioactive compounds and antioxidant activity of wheat microgreen extract. Food Chem. 2020, 309, 125763. [CrossRef]

108. Phattarakul, N.; Rerkasem, B.; Li, L.J. Biofortification of rice grain with zinc through zinc fertilization in different countries. Plant Soil 2012, 361, 131-141. [CrossRef]

109. Rodrigo, S.; Santamaria, O.; Poblaciones, M.J. Selenium Application Timing: Influence in Wheat Grain and Flour Selenium Accumulation under Mediterranean Conditions. J. Agric. Sci. 2014, 6, 6. [CrossRef]

110. Signore, A.; Renna, M.; D’Imperio, M.; Serio, F.; Santamaria, P. Preliminary evidences of biofortification with iodine of "carota di polignano", an Italian carrot landrace. Front. Plant Sci. 2018, 9, 1-8. [CrossRef]

111. Izydorczyk, G.; Ligas, B.; Mikula, K.; Witek-Krowiak, A.; Moustakas, K.; Chojnacka, K. Biofortification of edible plants with selenium and iodine-A systematic literature review. Sci. Total Environ. 2021, 754, 141983. [CrossRef]

112. White, P.J.; Broadley, M.R. Biofortification of crops with seven mineral elements often lacking in human diets-Iron, zinc, copper, calcium, magnesium, selenium and iodine. New Phytol. 2009, 182, 49-84. [CrossRef] 
113. Rosa, A.T.; Diaz, D.A.R.; Hansel, F.D.; Sebastian, J.S.V.; Adee, E.A. Genotypic Variation on Root Growth and Nutrient Uptake in Corn and Soybean. Agrosyst. Geosci. Environ. 2019, 2, 1-12. [CrossRef]

114. Clark, R.B. Plant genotype differences in the uptake, translocation, accumulation, and use of mineral elements required for plant growth. Plant Soil 1983, 72, 175-196. [CrossRef]

115. Saha, S.; Chakraborty, M.; Padhan, D.; Saha, B.; Murmu, S.; Batabyal, K.; Seth, A.; Hazra, G.C.; Mandal, B.; Bell, R.W. Agronomic biofortification of zinc in rice: Influence of cultivars and zinc application methods on grain yield and zinc bioavailability. Field Crop. Res. 2017, 210, 52-60. [CrossRef]

116. Ramzani, P.M.A.; Khalid, M.; Naveed, M.; Irum, A.; Kausar, S. Iron Biofortification of Cereals Grown under Calcareous Soils: Problems and Solutions. In Soil Science: Agricultural and Environmental Prospectives; Springer: Cham, Switzerland, 2016 ; pp. 232-258. ISBN 9783319344515.

117. Barbosa, G.L.; Gadelha, F.D.A.; Kublik, N.; Proctor, A.; Reichelm, L.; Weissinger, E.; Wohlleb, G.M.; Halden, R.U. Comparison of land, water, and energy requirements of lettuce grown using hydroponic vs. Conventional agricultural methods. Int. J. Environ. Res. Public Health 2015, 12, 6879-6891. [CrossRef]

118. Bhardwaj, D.; Ansari, M.W.; Sahoo, R.K.; Tuteja, N. Biofertilizers function as key player in sustainable agriculture by improving soil fertility, plant tolerance and crop productivity. Microb. Cell Fact. 2014, 13, 1-10. [CrossRef]

119. Sahoo, R.K.; Bhardwaj, D.; Tuteja, N. Biofertilizers: A Sustainable Eco-Friendly Agricultural Approach to Crop Improvement. In Plant Acclimation to Environmental Stress; Springer: New York, NY, USA, 2013; pp. 403-432. ISBN 9781461450016.

120. Mishra, D.J.; Rajvir, S.; Mishra, U.K.; Kumar, S.S. Role of Bio-Fertilizer in Organic Agriculture: A Review. Res. J. Recent Sci. ISSN 2020, 2, 39-41.

121. Rengel, Z.; Batten, G.D.; Crowley, D.E. Agronomic approaches for improving the micronutrient density in edible portions of field crops. Field Crop. Res. 1999, 60, 27-40. [CrossRef]

122. Hazra, G. Different Types of Eco-Friendly Fertilizers: An Overview. Sustain. Environ. 2016, 1, 54. [CrossRef]

123. Naguib, N.Y.M. Organic vs. chemical fertilization of medicinal plants: A concise review of researches. Adv. Environ. Biol. 2011, 5, 394-400.

124. Li, B.Y.; Zhou, D.M.; Cang, L.; Zhang, H.L.; Fan, X.H.; Qin, S.W. Soil micronutrient availability to crops as affected by long-term inorganic and organic fertilizer applications. Soil Tillage Res. 2007, 96, 166-173. [CrossRef]

125. Maleki, F.S.; Chaichi, M.R.; Mazaheri, D.; Tavakkol, A.R.; Savaghebi, G. Barley Grain Mineral Analysis as Affected by Different Fertilizing Systems and by Drought Stress. J. Agric. Sci. Technol. 2011, 13, 315-326.

126. Ramzani, P.M.A.; Khalid, M.; Naveed, M.; Ahmad, R.; Shahid, M. Iron biofortification of wheat grains through integrated use of organic and chemical fertilizers in pH affected calcareous soil. Plant Physiol. Biochem. 2016, 104, 284-293. [CrossRef]

127. Ramzani, P.M.A.; Khalid, M.; Anjum, S.; Ali, S.; Hannan, F.; Iqbal, M. Cost-effective enhanced iron bioavailability in rice grain grown on calcareous soil by sulfur mediation and its effect on heavy metals mineralization. Environ. Sci. Pollut. Res. 2017, 24, 1219-1228. [CrossRef]

128. Chen, Z.; Jiang, X. Microbiological Safety of Chicken Litter or Chicken Litter-Based Organic Fertilizers: A Review. Agriculture 2014, 4, 1-29. [CrossRef]

129. Kyakuwaire, M.; Olupot, G.; Amoding, A.; Nkedi-Kizza, P.; Basamba, T.A. How safe is chicken litter for land application as an organic fertilizer? A review. Int. J. Environ. Res. Public Health 2019, 16, 3521. [CrossRef] [PubMed]

130. Gupta, A.; Hussain, N. A critical study on the use, application and effectiveness of organic and inorganic fertilizers. J. Ind. Pollut. Control 2014, 30, 191-193.

131. Prasanna, R.; Bidyarani, N.; Babu, S.; Hossain, F.; Shivay, Y.S.; Nain, L. Cyanobacterial inoculation elicits plant defense response and enhanced Zn mobilization in maize hybrids. Cogent Food Agric. 2015, 1, 1-13. [CrossRef]

132. Ramesh, A.; Sharma, S.K.; Sharma, M.P.; Yadav, N.; Joshi, O.P. Inoculation of zinc solubilizing Bacillus aryabhattai strains for improved growth, mobilization and biofortification of zinc in soybean and wheat cultivated in Vertisols of central India. Appl. Soil Ecol. 2014, 73, 87-96. [CrossRef]

133. Alori, E.T.; Babalola, O.O. Microbial inoculants for improving crop quality and human health in Africa. Front. Microbiol. 2018, 9, 1-12. [CrossRef] [PubMed]

134. Fierer, N. Embracing the unknown: Disentangling the complexities of the soil microbiome. Nat. Rev. Microbiol. 2017, 15, 579-590. [CrossRef] [PubMed]

135. Fierer, N.; Jackson, R.B. The diversity and biogeography of soil bacterial communities. Proc. Natl. Acad. Sci. USA 2006, 103, 626-631. [CrossRef] [PubMed]

136. Farooq, M.; Usman, M.; Nadeem, F.; Rehman, H.U.; Wahid, A.; Basra, S.M.A.; Siddique, K.H.M. Seed priming in field crops: Potential benefits, adoption and challenges. Crop Pasture Sci. 2019, 70, 731-771. [CrossRef]

137. Raj, A.B.; Raj, S.K. Seed priming: An approach towards agricultural sustainability. J. Appl. Nat. Sci. 2019, 11, 227-234. [CrossRef]

138. Lutts, S.; Benincasa, P.; Wojtyla, L.; Kubala, S.; Pace, R.; Lechowska, K.; Quinet, M.; Garnczarska, M. Seed Priming: New Comprehensive Approaches for an Old Empirical Technique. In New Challenges in Seed Biology—Basic and Translational Research Driving Seed Technology; Intech Open: London, UK, 2016.

139. Sher, A.; Sarwar, T.; Nawaz, A.; Ijaz, M.; Sattar, A.; Ahmad, S. Methods of Seed Priming; Springer Nature: Gateway East, Singapore, 2019; ISBN 9789811386251. 
140. Harris, D.; Rashid, A.; Miraj, G.; Arif, M.; Yunas, M. “On-farm” seed priming with zinc in chickpea and wheat in Pakistan. Plant Soil 2008, 306, 3-10. [CrossRef]

141. Praharaj, S.; Singh, R.; Singh, V.K.; Chandra, R. Yield and grain zinc concentration of wheat as affected by nutri priming and foliar application of zinc. J. Pharmacogn. Phytochem. 2019, 8, 503-505.

142. Holub, B.J.; Nagpurkar, A. Method of Fortifying Seeds with an Essential Fatty Acid, Fortified Seed and Food Product. U.S. Patent 7416752, 26 August 2008.

143. Waqas, M.; Korres, N.E.; Khan, M.D.; Nizami, A.; Deeba, F.; Ali, I.; Hussain, H. Priming and Pretreatment of Seeds and Seedlings; Springer: Singapore, 2019; ISBN 9789811386251. 